\title{
Epigenetički biomarkeri u presađivanju bubrega
}

\section{Epigenetic biomarkers in kidney transplantation}

\author{
Klara Frančić ${ }^{*}$, Nataša Katalinić, Sanja Balen
}

\begin{abstract}
Sažetak. Križna proba, koncentracija kreatinina u serumu i procjena glomerularne filtracije, proteinurije te patohistološki nalaz biopsijom dobivenoga tkiva presatka biološki su markeri koji se koriste u transplantacijskoj medicini. Razvoj genetike i novih tehnologija omogućio je otkriće novih biomarkera kao ranih prediktora akutne reakcije odbacivanja, odgođene funkcije presatka, ishemijsko-reperfuzijske ozljede, intersticijske fibroze i atrofije tubula te dugoročnoga preživljavanja presatka. Radi boljega razumijevanja utjecaja okolišnih čimbenika na humani genom i njihove povezanosti s imunosnim odgovorom u presađivanju bubrega, provedena su brojna istraživanja o epigenetičkim mehanizmima. Cilj je rada prikazati potencijalne epigenetičke biomarkere, produkte epigenetičkih mehanizama i njihovu važnost $\mathrm{u}$ ishodu presađivanja bubrega.
\end{abstract}

Ključne riječi: biomarkeri; epigenetički mehanizmi; presađivanje bubrega; preživljavanje presatka

\begin{abstract}
Currently used prognostic biomarkers in kidney transplantation are - crossmatch, serum creatinine concentration and evaluation of glomerular filtration rate, proteinuria and a histopathological analysis of graft biopsy. The development of genetics and new technologies has enabled the discovery of new biomarkers as early predictors of acute rejection response, delayed graft function, ischemia-reperfusion injury, interstitial fibrosis, tubular atrophy and long-term graft survival. Numerous studies have been conducted to examine the influence of environmental factors on human genome and its relation with the immune response in kidney transplantation. The aim of this article is to present potential epigenetic biomarkers the products of epigenetic mechanisms, and their importance in the outcome of renal transplantation.
\end{abstract}

Key words: biomarkers; epigenetic processes; graft survival; renal transplantation
Klinički zavod za transfuzijsku medicinu, Klinički bolnički centar Rijeka, Rijeka, Hrvatska

\author{
*Dopisni autor: \\ Klara Frančić, dr. med. \\ Klinički zavod za transfuzijsku medicinu, \\ Klinički bolnički centar Rijeka \\ Tome Strižića 3, 51000 Rijeka \\ E-mail: klara.francic@gmail.com
}

http://hrcak.srce.hr/medicina 
UVOD - BIOMARKERI KOJI SE DANAS KORISTE U PRESADIVANJU BUBREGA

Glavni uzroci oštećenja bubrežne funkcije i obolijevanja od kroničnoga bubrežnog zatajenja (KBZ-a) jesu šećerna bolest tipa 2 i visoki krvni tlak. Svjetska zdravstvena organizacija upozorava na javnozdravstveni problem godišnjega porasta broja pacijenata s KBZ-om koji postaju ovisni o jednome od postupaka nadomještaja bubrežne funkcije - hemodijalizi, peritonejskoj dijalizi ili

Potencijalni epigenetički biomarkeri u presađivanju bubrega jesu produkti epigenetičkih mehanizama u darivatelja i primatelja prije i poslije presađivanja. Prednost je njihova korištenja u kliničkoj praksi u mogućnosti njihove rane detekcije i prediktivnoj vrijednosti mogućih nepoželjnih događaja s presatkom.

presađivanju bubrega ${ }^{1,2}$. Prema istraživanjima kvalitete života (engl. quality of life; QoL) većina pacijenata 12 mjeseci poslije presađivanja bubrega navodi bolju kvalitetu života, svakodnevno funkcioniranje u obitelji, na radnome mjestu i u društvenoj zajednici u odnosu na pacijente liječene hemodijalizom ili peritonejskom dijalizom ${ }^{3}$. Pritom su poboljšanjem kvalitete života zadovoljniji primatelji bubrega koji su prije zahvata bili ovisni o hemodijalizi od onih ovisnih o peritonejskoj dijalizi ${ }^{4}$.

Hrvatska je 2007. godine postala punopravna, a danas je najuspješnija članica Eurotransplanta međunarodne organizacije za dodjelu i razmjenu organa. Od 2010. godine godišnja je stopa darivatelja organa u Hrvatskoj neprestano iznad 30 darivatelja na milijun stanovnika, što nas, sa stopom presađivanja solidnih organa višom od 86 na milijun stanovnika, svrstava među države s najučinkovitijim transplantacijskim sustavom na svijetu. Godine 2018. u Hrvatskoj su presađena ukupno 183 bubrega, od čega 32 u Kliničkom bolničkom centru Rijeka ${ }^{5}$.

$\mathrm{U}$ velikom istraživanju koje je obuhvatilo ishod 108787 presađivanja bubrega u europskim centrima, petogodišnje preživljavanje bubrega presađenih između 2006. i 2015. iznosilo je 84,4\%. Studija je pokazala napredak u kratkotrajnome preživljavanju presatka, dok je poboljšanje dugoročnoga preživljavanja ostalo nepromijenjeno kroz praćeno razdoblje ${ }^{6}$. Razlog su tome složenost $\mathrm{i}$ istovremeno djelovanje neimunoloških i imunoloških čimbenika rizika darivatelja i primatelja. Oni se očituju u primjeru kumulativne ozljede organa darivatelja koja je rezultat neimunoloških okolnosti kao što su starost darivatelja, moždana smrt, ishemijsko-reperfuzijska ozljeda, gubitak nefrona te imunoloških okolnosti, poput infekcije i čimbenika vezanih uz HLA podudarnost"

U odluci o prihvaćanju bubrega te u praćenju njegove funkcije nakon presađivanja važnu ulogu imaju biomarkeri (biološki markeri), objektivno mjerljivi indikatori fizioloških, patoloških ili farmakoloških procesa ${ }^{8}$.

Idealan biomarker u procjeni funkcije presađenoga bubrega trebao bi imati svojstvo visoke prediktivne vrijednosti za oštećenja presatka koja još nisu vidljiva patohistološki, uz uvid u mehanizam nastanka oštećenja, trebao bi biti lako dostupan neinvazivnim metodama (npr. mjerljiv u krvi i urinu) te visoko osjetljiv i specifičan s obzirom na vrstu i mjesto oštećenja presađenoga bubrega ${ }^{9}$. Jedan od neizostavnih biomarkera prije presađivanja bubrega jest križna proba (engl. crossmatch) u testu citotoksičnosti ovisne o komplementu (engl. complement-dependent cytotoxicity; CDC) između limfocita darivatelja i seruma primatelja. Pozitivna križna proba imunološka je reakcija uzrokovana vezanjem ljudskih leukocitnih antigena (engl. human leukocyte antigen; HLA) izraženih na stanicama presatka sa specifičnim antitijelima HLA u serumu primatelja ${ }^{10}$. Zbog povezanosti donorspecifičnih antitijela (engl. donor specific antibody) s (hiper)akutnim odbacivanjem presatka, negativna križna proba preduvjet je uspješnoga presađivanja bubrega ${ }^{11}$.

Uz križnu probu, danas se u transplantacijskoj medicini koriste sljedeći prognostički biomarkeri - koncentracija kreatinina u serumu i procjena glomerularne filtracije, proteinurije te patohistološki nalaz biopsijom dobivenoga tkiva presatka ${ }^{12}$. Glomerularna je filtracija kao pokazatelj funkcije bubrega određena koncentracijom kreatinina $u$ serumu i njegovim klirensom ${ }^{13}$. Koncentracija kreatinina u serumu ovisi o oštećenju funkcije presatka, ali i o brojnim čimbenicima kao što su dob, spol, prehrana, mišićna masa, hidracija i slič- 
no. Ona ima loš prognostički značaj, posebice u akutnome odbacivanju presatka jer može ostati nepromijenjena sve dok se funkcija bubrega ne smanji za gotovo $50 \%$. U tom je slučaju nepovratno izgubljeno vrijeme za uvođenje farmakološke terapije, pa izostaju očekivani rezulati liječenja ${ }^{14}$. Proteinurija se javlja u 35 do $45 \%$ pacijenata u prvoj godini nakon presađivanja bubrega. Najčešći je biomarker tubularne bolesti presatka koja je ili rekurentna ili je posljedica imunološke reakcije antitijela HLA-razreda II $^{15}$.

Rezultat patohistološke analize tkiva presatka je zlatni standard u odlučivanju prihvaćanja ponuđenoga bubrega, kao i u praćenju njegove funkcije nakon presađivanja. No, biopsija je invazivna tehnika, a patološke promjene bubrega nisu homogene već heterogene te ovise o dijelu bubrega kojemu uzeti uzorak pripada. Zbog heterogenosti promjena bubrega moguće je da biopsijom dobiveno tkivo presatka nije zahvaćeno promjenom, dok ostatak tkiva jest, čime prediktivna vrijednost biopsije postaje upitna ${ }^{16}$.

Unatoč desetljećima iskustva i praćenja pacijenata prije i poslije presađivanja bubrega te biomarkerima koji se koriste u kliničkoj praksi, postoji velika potreba za novim biomarkerima koji bi najavili poremećaj prije nastanka patohistoloških promjena presatka. Cilj je ovoga rada prikazati potencijal koji čine otkrivanje i razvoj epigenetičkih biomarkera koji bi, uz genetičke biomarkere, omogućili ne samo kvalitetnije praćenje pacijenata nakon presađivanja, već bi imali važnu prediktivnu vrijednost prije presađivanja, a time i pozitivno utjecali na dugoročno preživljavanje presatka.

\section{POTENCIJALNI EPIGENETIČKI BIOMARKERI} U PRESADIVANJU BUBREGA

Epigenetički mehanizmi reguliraju gensku aktivnost u stanici mijenjajući izražaj (ekspresiju) gena bez promjena u slijedu nukleotida molekule DNA $^{17}$. Djeluju na razini poticanja ili kočenja transkripcije i translacije gena u proteine. Time izravno utječu na izražaj jednih gena i utišavanje drugih ${ }^{18}$. Epigenetički događaji u ljudskome organizmu pod utjecajem su okolišnih čimbenika - dobi, životnih navika (npr. prehrane, tjelovježbe, pušenja) i oksidacijskoga stresa ${ }^{19}$.
Epigenetički mehanizmi koji djeluju u darivatelju i za vrijeme bubrežne bolesti primatelja prije te poslije presađivanja, ostavljaju trag koji je potencijalno vrijedan biomarker. Epigenetički biomarker daje klinički važnu informaciju predorganskoga oštećenja (prije vidljivih patohistoloških promjena) na razini produkata gena (proteina) i nekodirajućih molekula RNA. Ta bi prednost epigenetičkih biomakera spram ostalih biomarkera koji se danas koriste omogućila prevenciju oštećenja presatka pravovremenom farmakološkom terapijom. Uz navedeno, njihova je prednost i u neinvazivnoj tehnici prikupljanja (za razliku od biopsijom dobivenih rezultata), odnosno lakoj dostupnosti te stabilnosti u krvi i urinu. Nekoliko istraživača dokazalo je prisutnost nekodirajućih molekula RNA u odmrznutim uzorcima, mogućnost detekcije metilacije DNA u arhiviranoj osušenoj krvi te mogućnost analize metilacije DNA neovisno o uvjetima skladištenja ${ }^{20}$.

EPIGENETIČKI MEHANIZMI KOJI UTJEČU NA PRESADIVANJE BUBREGA

Epigenetički mehanizmi jesu metilacija molekule DNA, demetilacija molekule DNA, modifikacija histona te utišavanje gena aktivnošću nekodirajućih molekula RNA ${ }^{21}$. Metilacijom regija DNA onemogućena je transkripcija gena, dok demetilacija regija DNA i acetilacija histona omogućavaju transkripciju. Nekodirajuće molekule RNA inhibiraju translaciju glasničke mRNA (engl. messenger RNA; mRNA) ili potiču njezinu razgradnju ${ }^{22}$ (slika 1 ).

\section{Utjecaj (hiper)metilacije i demetilacije DNA na događaje prije i poslije presađivanja bubrega}

Povezanost kronološke i epigenetičke dobi sa strukturalnim promjenama presatka

Metilacija se molekule DNA uvijek događa na citozinu kojeg slijedi guanin na istome lancu, tvoreći tako citozin-guanin dinukleotid, tzv. CpG-mjesta (engl. CpG sites). Za metilaciju, odnosno dodavanje $-\mathrm{CH}_{3}$ skupine, odgovorna je jedna od DNA-metiltransferaza (engl. DNA methyltransferase; DNMT). U humanome je genomu oko 80 \% CpG-mjesta metilirano. Nemetilirani CpG dinukleotidi organizirani su unutar takozvanih CpG-otoka (engl. CpG islands) koji su dio promotora gena. Njihovom se metilacijom i hipermetilacijom geni utišavaju ${ }^{23}$. 


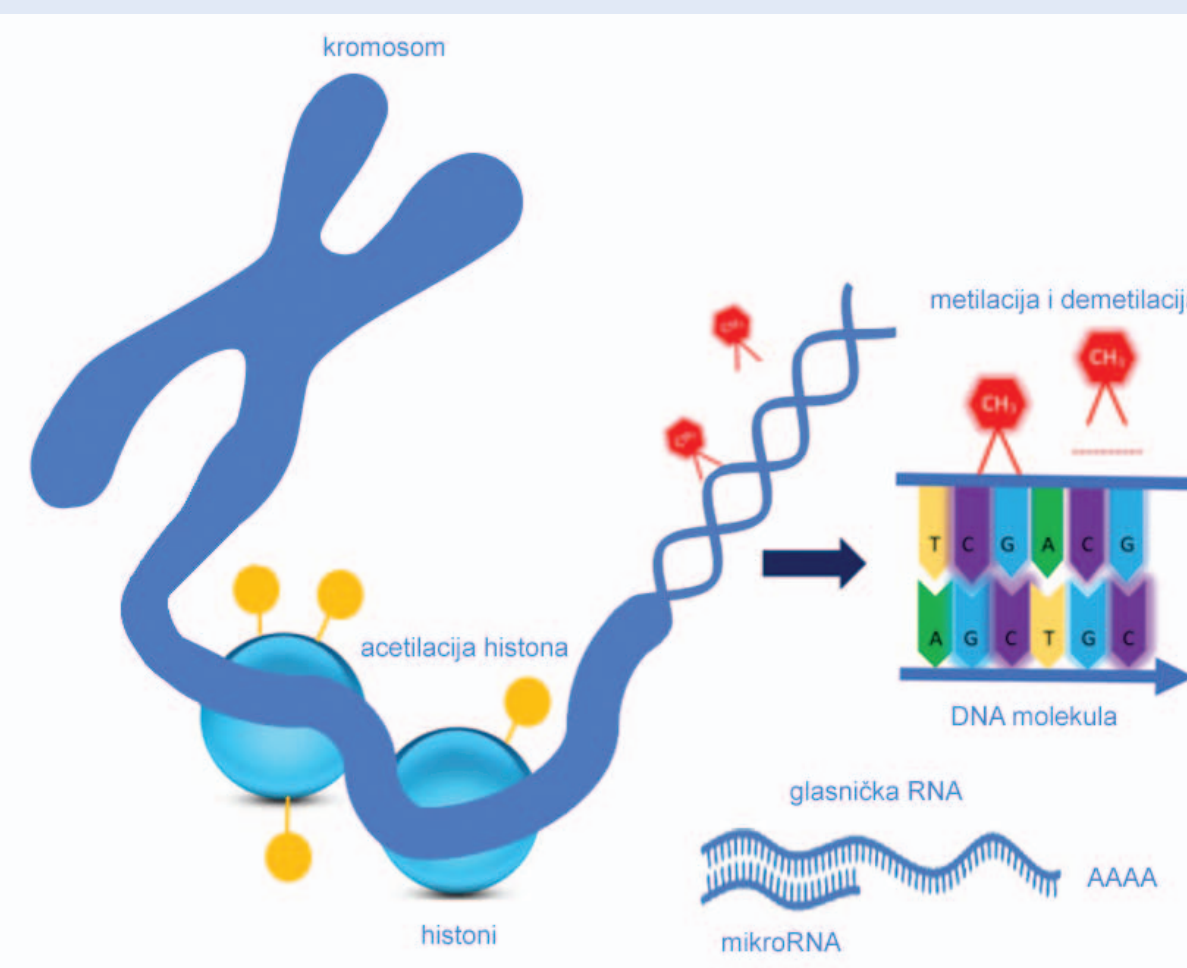

Slika 1. Shematski prikaz epigenetičkih mehanizama u presađivanju bubrega

Dob darivatelja negativno utječe na dugoročno preživljavanje presatka jer se funkcija bubrega starenjem smanjuje. Kronološku dob najčešće prati i epigenetička dob darivatelja koja ovisi o epigenetičkim čimbenicima koji djeluju u darivatelju prije presađivanja bubrega ${ }^{24}$. Starenjem se broj hipermetiliranih CpG-mjesta povećava, što su dokazali Heylen i suradnici u istraživanju objavljenome 2019. godine. U presadcima bubrega 95 darivatelja prije presađivanja detektirali su specifična hipermetilirana CpG-mjesta prisutna samo u darivatelja starije životne dobi. Od svih detektiranih CpG-mjesta, u starijoj životnoj dobi darivatelja, hipermetiliranih je CpG-mjesta bilo $74 \%$. U tih su presadaka godinu dana nakon presađivanja biopsijom utvrđene i glomeruloskeroza i intersticijska fibroza, što ukazuje na to da dokazana hipermetilacija prije presađivanja korelira sa strukturalnim promjenama bubrega godinu dana nakon presađivanja ${ }^{25}$. To upućuje na povezanost hipermetilacije i utišanosti gena važnima u signalnim putovima glomeruloskleroze i intersticijske fibroze. Bontha i suradnici, u istraživanju koje je obuhvatilo 99 uzoraka biopsije presatka bubrega, dokazali su hipermetilaciju DNA na promotorima gena odgovornima u fibrinogenezi, metaboličkoj funkciji i promjeni strukture bubrega dvije godine poslije presađivanja bubrega. Prvi su dokazali povezanost epigenetičkih mehanizama s promjenom funkcije presatka, razvojem intersticijske fibroze i tubularne atrofije te posljedičnim utjecajem na dugoročni ishod presađivanja ${ }^{26}$.

\section{Ishemijsko-reperfuzijska ozljeda presatka}

Ishemijsko-reperfuzijska ozljeda presatka bubrega s preminuloga darivatelja jest posljedica patofizioloških događaja nastalih tijekom ishemije i ponovne uspostave krvotoka nakon ishemije. Ona loše utječe na odgođenu funkciju i na dugoročno preživljavanje bubrežnoga presatka. Njezin je utjecaj na epigenetičke mehanizme organa darivatelja višestruk. Zbog ishemije i oksidacijskoga stresa koji uzrokuju reorganizaciju i mutacije DNA u darivatelja, posljedično dolazi i do povećane metilacije $e^{27,28}$. Heylen i suradnici, u istraživanju objavljenome 2018. godine, prvi su dokazali da su hipermetilacijom (uzrokovanom hipoksijom zbog ishemijsko-reperfuzijske ozljede presatka) utišani geni koji sudjeluju u očuvanju funkcije presađenoga bubrega. Identificirali su hipermetilaciju 
DNA kao epigenetički biomarker koji je proporcionalan trajanju hladne ishemije te visokoprediktivan za kronično oštećenje presatka, posebice za razvoj intersticijske fibroze i glomeruloskleroze godinu dana poslije presađivanja ${ }^{29}$.

\section{Akutno odbacivanje presatka}

Metilacija i demetilacija DNA potencijalni su biomarkeri u praćenju imunološkoga odgovora primatelja nakon presađivanja jer utječu na izražaj antigena HLA-razreda I i II na stanicama presatka. T-stanice se inaktiviraju metilacijom regije promotora gena interleukina- $2^{30}$. Također, metilacija i demetilacija reguliraju aktivnost NK-stanica, receptore kemokina T-stanica CD4+ te ekspresiju gena FOXP3 važnoga za prigušivanje imunosnoga odgovora koje je omogućeno demetilacijom i transkripcijom, a onemogućeno metilacijom. Hipermetilacija promotora CALCA (engl. calcitonin gene-related polypeptide-alpha) kalcitoninskih gena koji su dokazano povezani s tumorskim mehanizmima, detektirana je u urinu primatelja presatka preminuloga darivatelja te u događajima akutnoga odbacivanja, kao i u odgođenoj funkciji presatka $^{31}$.

\section{Modifikacija histona i njen utjecaj na događaje prije i poslije presađivanja bubrega}

Modifikacija histona uvjetovana je dvjema enzimatskim skupinama oprečnoga djelovanja - acetiltransferazama (engl. histone acety/transferases; HATs) i deacetilazama (engl. histone deacetylases; HADCs). Acetiliranjem histona opušta se struktura kromatina, čime je omogućena transkripcija dijelova molekule DNA koje inače nisu dostupne transkripcijskim čimbenicima. Smanjena transkripcija i utišavanje genskoga izražaja posljedica su deacetilacije histona ${ }^{32}$.

Ishemijsko-reperfuzijska ozljeda, vrijeme hladne ishemije i hipoksije kojima je presadak izložen, smanjuju aktivnost acetiltransferaze. Inhibitori skupine deacetilaza imaju protuupalni učinak te zaustavljaju fibrozu tkiva bubrega, što se potencijalno može koristiti u mehanizmu djelovanja imunosupresivne terapije ${ }^{33}$. Dosadašnje spoznaje temelje se na istraživanjima provedenima na životinjskim modelima, stoga su neophodne daljnje studije koje bi u budućnosti imale klinički značaj $^{34-37}$.

\section{Utjecaj nekodirajućih molekula RNA na događaje prije i poslije presađivanja bubrega}

Nekodirajuće molekule RNA (engl. non-coding RNAs; ncRNAs) ne prepisuju se u protein, a imaju neminovno važnu ulogu u epigenetičkim, transkripcijskim i posttranskripcijskim događajima. S obzirom na veličinu, nekodirajuće molekule RNA klasificiraju se u velike i male.

Velike nekodirajuće molekule RNA (engl. long non-coding RNAs; IncRNAs) veće su od 200 nukle-

Epigenetički mehanizmi koji utječu na izražajnost gena važnih u presađivanju bubrega jesu metilacija i demetilacija DNA, acetilacija histona i aktivnost nekodirajućih molekula RNA. Oni sudjeluju u regulaciji aktivnosti gena odgovornih za akutnu reakciju odbacivanja, odgođenu funkciju presatka, ishemijsko-reperfuzijsku ozljedu, intersticijsku fibrozu i atrofiju tubula presatka.

otida i važni su modulatori u interakciji s DNA, RNA i proteinima ${ }^{38}$. Lorenzen i suradnici predložili su tri, u urinu detektirane, molekule IncRNA kao buduće biomarkere čija je povišena vrijednost posljedica upalnih procesa odgovornih za odbacivanje presatka jednu godinu nakon presađivanja bubrega. Djelujući putem eznima MGAT3 (engl. mannosylglycoprotein 4-8-N-acetylglucosaminyltransferase), koji je odgovoran za poticanje aktivnosti mononuklearnih stanica i fagocitoze, molekule IncRNA sudjeluju u upalnim procesima te su potencijalni biomarkeri odgođene funkcije presatka preminuloga darivatelja ${ }^{39}$. Qiu i suradnici ukazali su na povezanost IncRNA s transformirajućim čimbenikom rasta TGF- $\beta$ (engl. transforming growth factor beta) koji je odgovoran za intersticijsku fibrozu i zatajenje bubrega. Franco-Acevedo i suradnici ističu tri molekule IncRNA - AF264622 i AB209021 koje su povišene u krvi u akutnoj reakciji odbacivanja u djece i u odraslih poslije presađivanja te RP11-354P17.15-001 koja je povišena u urinu u reakciji odbacivanja posredovanom T-stanicama (engl. $T$ cell-mediated rejection; TCMR) i povezana s padom glomerularne filtracije šest tjedna nakon presađivanja, a čija se vrijednost u urinu smanjuje nakon primjene imunosupresivne terapije ${ }^{40}$. Shang i suradnici prikaza- 
li su različite obrasce ekspresije IncRNA u primatelja u kojih se nakon presađivanja razvio karcinom prijelaznoga epitela mokraćnoga mjehura te sugerirali da molekule IncRNA imaju ključnu ulogu u njegovoj karcinogenezi ${ }^{39}$.

Male nekodirajuće molekule RNA (engl. small non-coding RNAs; sncRNAs) manje su od 200 nukleotida. Jedna vrsta malih nekodirajućih molekula RNA jesu mikroRNA (engl. microRNA; miRNA) sastavljene od 21 do 25 nukleotida. One reguliraju izražaj gena nakon transkripcije cijepanjem i razgradnjom mRNA ${ }^{41}$.

Jedna molekula miRNA regulira izražaj više različitih gena, pa je tako moguće otkrivanje i praćenje novih kaskada i signalnih putova koji sudjeluju u obnovi i ozljedi bubrega prije i nakon presađivanja ${ }^{42}$. Molekule miRNA važne su u međustaničnoj komunikaciji, a oslobađaju se ili pasivno oštećenjem i smrću stanice ili aktivno u kompleksu s RNA vezujućim proteinima koji ih štite od razgradnje RNaza. Njihova je stabilnost u serumu i urinu važna zbog njihove potencijalne uloge biomarkera. Imaju važnu epigenetičku ulogu u kroničnome bubrežnom zatajenju i presađivanju bubrega ${ }^{43}$.

Kao potencijalni biomarkeri akutnoga odbacivanja presatka i ishemijsko-reperfuzijske ozljede, miRNA imaju važnu ulogu u regulaciji upalnih procesa, proizvodnji upalnih citokina i kemokina, migraciji, adheziji stanica $i$ apoptozi ${ }^{44}$. S druge strane, miRNA prisutne $u$ urinu tijekom intersticijske fibroze i atrofije tubula sudjeluju u proliferaciji limfocita te $\mathrm{u}$ aktivaciji i diferencijaciji B-limfocita, T-limfocita i NK-stanica ${ }^{43}$.

MiRNA-21 jest specifična miRNA jer njezinu aktivnost možemo pratiti u svim događajima presađivanja bubrega, a prisutna je i u neaktivnome obliku u zdravome tkivu bubrega ${ }^{41}$. Stabilna je i nakon nekoliko ciklusa smrzavanja i odmrzavanja u uzorku urina, kao i nakon inkubacije unutar 24 sata na sobnoj temperaturi, što je čini dobrim biomarkerom $^{44,45}$.

$U$ ishemijsko-reperfuzijskoj ozljedi ima dvojaku ulogu - antiapoptotičku i antiinflamatornu u kratkome vremenu te profibrotičku u produženome vremenu ishemije. Khalid i suradnici izmjerili su povišenu koncentraciju miRNA-21 u urinu 33 primatelja s odgođenom funkcijom presatka u prvih pet dana nakon presađivanja bubrega ${ }^{46}$. U istraživanju objavljenome 2014. godine Glowacki i suradnici prvi su dokazali da se vrijednosti koncentracije miRNA-21 u krvi povisuju napredovanjem intersticijske fibroze $i$ atrofije tubula presatka ${ }^{47}$. Zununi Vahed i suradnici utvrdili su povišene vrijednosti koncentracije miRNA-21 u plazmi 26 primatelja kojima je biopsijom dokazana intersticijska fibroza i atrofija tubula ${ }^{48}$.

\section{ZAKLJUČAK}

Epigenetički mehanizmi koji djeluju u darivatelju i primatelju organa prije i poslije presađivanja predstavljaju velik izazov u razumijevanju problematike odbacivanja i dugoročnoga preživljavanja presatka. Ubrzanim razvojem genetike i epigenetike te novim istraživanjima, skora upotreba epigenetičkih biomarkera, produkata epigenetičkih mehanizama, neminovna je u kliničkoj praksi. Prednost je epigenetičkih biomarkera u mogućnosti njihove rane detekcije i prediktivnoj vrijednosti mogućih nepoželjnih događaja povezanih s presatkom, koji se danas mogu uočiti tek kada se već razviju promjene na razini patohistološkoga nalaza biopsije presatka. Njihovom će upotrebom u kliničkoj praksi biti omogućena rana intervencija na razini predorganskih oštećenja, međutim, genetička su istraživanja otežana zbog velikoga broja podataka o promjenama u izražaju mnogobrojnih gena koji utječu i na napredovanje kronične bubrežne bolesti i na događaje prije i poslije presađivanja. Polazeći od rezultata dosadašnjih istraživanja, potrebno je provesti nova, na većem broju uzoraka, da bi se dokazala učinkovitost i korisnost epigenetičkih biomarkera.

Izjava o sukobu interesa: Autori izjavljuju da ne postoji sukob interesa.

\section{LITERATURA}

1. Luyckx V, Tonelli M, Stanifer JW. The global burden of kidney disease and the sustainable development goals. Bull World Health Organ. 2018;96:414-22.

2. Rački S, Orlić L, Sladoje-Martinović B. Kronično bubrežno zatajenje - indikacija za presađivanje bubrega. Medix 2011;92/93:195-201.

3. Czyżewski L, Sańko-Resmer J, Wyzgał J, Kurowski A. Assessment of Health-Related Quality of Life of Patients after Kidney Transplantation in Comparison with Hemodialysis and Peritoneal Dialysis. Ann Transplant. 2014;19: 576-85.

4. Kostro JZ, Hellmann A, Kobiela J, Skóra I, Lichodziejewska-Niemierko M, Dębska-Ślizień A et al. Quality of Life After Kidney Transplantation: A Prospective Study. Transplant Proc. 2016;48:50-4. 
5. Ministarstvo zdravstva Republike Hrvatske. Nacionalni transplantacijski program. Preliminarno izvješće 2018, Zavod za transplantacijsku i biomedicinu. [Internet] Inc. 2019 [cited 2019 Sep 28]. Available from: https://zdravlje.gov.hr/programi-i-projekti/nacionalni-programi-projekti-i-strategije/nacionalni-transplantacijski-program/ godisnja-izvjesca/1605.

6. Coemans $M$, Süsal C, Döhler B, Anglicheau D, Giral M, Bestard $O$ et al. Analyses of the short- and long-term graft survival after kidney transplantation in Europe between 1986 and 2015. Kidney Int. 2018;94:964-73.

7. Mas VR, Le TH, Maluf DG. Epigenetics in Kidney Transplantation: Current Evidence, Predictions, and Future Research Directions. Transplantation. 2016;100:23-38.

8. Mas VR, Mueller TF, Archer KJ, Maluf DG. Identifying biomarkers as diagnostic tools in kidney transplantation. Expert Rev Mol Diagn. 2011;11:183-96.

9. Emerging Safety Science: Workshop Summary. Qualifying Biomarkers [Internet]. Inc. 2008. [cited 2019 Sep 23]. Available from: https://www.ncbi.nlm.nih.gov/books/ NBK4041/.

10. Althaf MM, Kossi ME, Jin JK, Sharma A, Halawa AM. Human leukocyte antigen typing and crossmatch: A comprehensive review. World J Transplant. 2017;7:339-48.

11. Safa K, Magee CN, Azzi J. A critical review of biomarkers in kidney transplantation. Curr Opin Nephrol Hypertens. 2017; 26:509-15

12. Naesens $M$, Anglicheau D. Precision Transplant Medicine: Biomarkers to the Rescue. JASN 2018:29:24-34.

13. Jurčić P. Značaj mjerenja glomerularne filtracije u nefrologiji i kardiologiji. Medicina Fluminensis. 2012;2:151-63.

14. Devarajan P. Update on mechanisms of ischemic acute kidney injury. J Am Soc Nephrol 2006;17:1503-20.

15. Suárez Fernández ML, G-Cosio F. Causes and consequences of proteinuria following a kidney transplantation. Nefrologia 2011;31:404-14.

16. Agodi A, Barchitta M, Maugeri A, Basile G, Zamboni M, Bernardini $G$ et al. Unveiling the Role of DNA Methylation in Kidney Transplantation: Novel Perspectives toward Biomarker Identification. Biomed Res Int. 2019;1-8.

17. Handy DE, Castro R, Loscalzo J. Epigenetic modifications: basic mechanisms and role in cardiovascular disease. Circulation. 2011;123:2145-56.

18. Cavalli G, Heard E. Advances in epigenetics link genetics to the environment and disease. Nature. 2019;571:48999.

19. Alegría-Torres JA, Baccarelli A, Bollati V. Epigenetics and lifestyle. Epigenomics. 2011;3: 267-77.

20. Strimbu K, Tavel JA. What are biomarkers? Curr Opin HIV AIDS. 2010;5:463-6.

21. Cañadas-Garre M, Anderson K, McGoldrick J, Maxwell AP, McKnight AJ, Genomic approaches in the search for molecular biomarkers in chronic kidney disease. J Transl Med 2018;16:292-7.

22. Moore DS. Behavioral epigenetics. WIREs Syst Biol Med 2017, 9:e1333. [Internet] Inc. c1999-2020 [cited 2019 Sep 28]. Available from: https://onlinelibrary.wiley.com/ doi/abs/10.1002/wsbm.1333.

23. Moore LD, Le T, Fan G. DNA methylation and its basic function. Neuropsychopharmacology. 2013;38:23-38.

24. Heylen L, Thienpont B, Naesens M, Lambrechts D, Sprangers B. The Emerging Role of DNA Methylation in
Kidney Transplantation: A Perspective. Am J Transplant. 2016;16:1070-8.

25. Heylen L, Thienpont B, Busschaert P, Sprangers B, Kuypers $D$, Moisse $M$ et al. Age-related changes in DNA methylation affect renal histology and post-transplant fibrosis. Kidney Int. 2019;96:1195-204.

26. Bontha SV, Maluf DG, Archer KJ, Dumur Cl, Dozmorov $M G$, King $A L$ et al. Effects of DNA methylation on progression to interstitial fibrosis and tubular atrophy in renal allograft biopsies: A multi-omics approach. American Journal of Transplantation. 2017;17:3060-75.

27. Franco R, Schoneveld O, Georgakilas AG, Panayiotidis MI. Oxidative stress, DNA methylation and carcinogenesis. Cancer Lett. 2008;266:6-11.

28. Rasmussen KD, Helin K. Role of TET enzymes in DNA methylation, development, and cancer. Genes Dev. 2016: 30:733-50.

29. Heylen L, Thienpont B, Naesens $M$, Busschaert $P$, Depreeuw J, Smeets D et al. Ischemia-Induced DNA Hypermethylation during Kidney Transplant Predicts Chronic Allograft Injury. J Am Soc Nephrol. 2018;29:1566-76.

30. Veroux $\mathrm{M}$, Corona $\mathrm{D}$, Veroux P. Kidney transplantation: Future challenges. Minerva Chir. 2009;64:75-100.

31. Mehta TK, Hoque MO, Ugarte R, Rahman MH, Kraus E, Montgomery R et al. Quantitative detection of promoter hypermethylation as a biomarker of acute kidney injury during transplantation. Transplant Proc. 2006;38: 3420-6.

32. Suganuma T, Workman JL. Signals and combinatorial functions of histone modifications. Annu Rev Biochem. 2011;80:473-99.

33. Morgado-Pascual JL, Marchant V, Rodrigues-Diez R, Dolade N, Suarez-Alvarez B, Kerr B. Epigenetic Modification Mechanisms Involved in Inflammation and Fibrosis in Renal Pathology. Mediators of Inflammation Volume 2018. [Internet] Inc. c2018 [cited 2019 Sep 28]. Available from: https://doi.org/10.1155/2018/2931049.

34. Levine MH, Wang Z, Bhatti TR, Wang Y, Aufhauser DD, McNeal $S$ et al. Class-specific histone/protein deacetylase inhibition protects against renal ischemia reperfusion injury and fibrosis formation. Am J Transplant. 2015;15: 965-73.

35. Bontha SV, Maluf DG, Mueller TF, Mas VR. Systems Biology in Kidney Transplantation: The Application of MultiOmics to a Complex Model. Am J Transplant. 2017;17: 11-21.

36. Ellis JD, Neil DA, Inston NG, Jenkinson E, Drayson MT, Hampson P et al. Inhibition of Histone Deacetylase 6 Reveals a Potent Immunosuppressant Effect in Models of Transplantation. Transplantation. 2016;100:1667-74.

37. Wang L, Beier UH, Akimova T, Dahiya S, Han R, Samanta A et al. Histone/protein deacetylase inhibitor therapy for enhancement of Foxp3+ T-regulatory cell function posttransplantation. Am J Transplant. 2018;18:1596603.

38. Moghaddas Sani H, Hejazian M, Hosseinian Khatibi SM, Ardalan M, Zununi Vahed S. Long non-coding RNAs: An essential emerging field in kidney pathogenesis. Biomed Pharmacother. 2018;99:755-65.

39. Ignarski M, Islam R, Müller RU. Long Non-Coding RNAs in Kidney Disease. Int J Mol Sci. 2019;20:327-89.

40. Franco-Acevedo A, Melo Z, Echavarria R. Diagnostic, Prognostic, and Therapeutic Value of Non-Coding RNA 
Expression Profiles in Renal Transplantation. Diagnostics. 2020;10:60-77.

41. Salvadori M, Tsalouchos A. Biomarkers in renal transplantation: An updated review. World J Transplant. 2017;7:161-78.

42. Jelencsics K, Oberbauer R. MicroRNA and Kidney Transplantation. Adv Exp Med Biol. 2015;888:271-90.

43. Ledeganck KJ, Gielis EM, Abramowicz D, Stenvinkel $P$, Shiels PG, Van Craenenbroeck AH. MicroRNAs in AKI and Kidney Transplantation. CJASN 2019;14:454-68.

44. Janszky N, Süsal C. Circulating and urinary microRNAs as possible biomarkers in kidney transplantation. Transplant Rev (Orlando). 2018;32:110-8.

45. Lorenzen JM, Volkmann I, Fiedler J, Schmidt M, Scheffner I, Haller $\mathrm{H}$ et al. Urinary miR-210 as a mediator of acute T-cell mediated rejection in renal allograft recipients. Am J Transplant. 2011;11:2221-7.

46. Khalid U, Newbury LJ, Simpson K, Jenkins RH, Bowen T, Bates $L$ et al. A urinary microRNA panel that is an early predictive biomarker of delayed graft function following kidney transplantation. Sci Rep. 2019;9:465-90.

47. Glowacki F, Savary G, Gnemmi V, Buob D, Van der Hauwaert C, Lo-Guidice JM et al. Increased circulating miR21 levels are associated with kidney fibrosis. PLoS One. 2013;8:1-11.

48. Zununi Vahed S, Poursadegh Zonouzi A, Ghanbarian H, Ghojazadeh M, Samadi N, Omidi Y et al. Differential expression of circulating miR-21, miR-142-3p and miR-155 in renal transplant recipients with impaired graft function. Int Urol Nephrol. 2017;49:1681-9. 